\title{
Electrocatalytic Oxidation of Sodium Borohydride on a Nanoporous $\mathrm{Ni} / \mathrm{Zn}-\mathrm{Ni}$ Electrode
}

\author{
Mir Ghasem HOSSEINI*, Mehdi ABDOLMALEKI, Sajjad ASHRAFPOOR \\ Electrochemistry Research Laboratory, Department of Physical Chemistry, Chemistry Faculty, University of Tabriz, Tabriz, Iran
}

\begin{abstract}
A Ni-Zn binary metal coating was electrochemically deposited on a copper electrode that was coated with nickel (bottom layer). This was then etched in concentrated alkaline solution $(30 \mathrm{wt} \% \mathrm{NaOH})$ to produce a nanoporous Ni electrocatalytic surface for borohydride electro-oxidation in alkaline solution. The bulk and surface compositions of the coating before and after alkaline leaching were determined by atomic absorption spectroscopy and energy dispersive X-ray analysis. The surface morphology was investigated by scanning electron microscopy. The characterization showed that the leached Ni/Zn-Ni coating has a nanoporous structure. Electrocatalytic activity for borohydride electro-oxidation was assessed by cyclic voltammetry and electrochemical impedance spectroscopy. The improved activity of the electrode was related to the removal of corrosion products and the formation of nanopores and cracks during alkaline leaching. Cyclic voltammetry studies confirmed that the alkaline leaching process improved the activity of the Ni/Zn-Ni coating in comparison to that of a smooth $\mathrm{Ni}$ deposit, and it gave an anodic peak current density that was 21 times higher.
\end{abstract}

Key words: leached Ni/Zn-Ni coating; electrochemical deposition; nanoporous; borohydride electro-oxidation; electrochemical impedance spectroscopy

CLC number: O643 Document code: A

Received 30 June 2012. Accepted 10 September 2012.

*Corresponding author.Tel: +98-41-13393138; Fax:+98-41-13340191; E-mail:mg-hosseini@tabrizu.ac.ir,mirghasem1970@yahoo.com This work was supported by Renewable Energy Organization of Iran and the financial support of the Office of Vice Chancellor in Charge of Research of University of Tabriz.

English edition available online at Elsevier ScienceDirect (http://www.sciencedirect.com/science/journal/18722067).

Recent studies using an alkaline medium [1,2] and the development of hydroxyl ion conducting membranes [3-7] have increased the interest in alkaline fuel cells (AFCs) [8-10], but the right fuel for these systems is still a key problem. Pure hydrogen or hydrogen-rich gases give high efficiency, but their production, storage, and distribution would constraint a large scale development $[11,12]$. The electro-oxidation of formic acid [13], methanol [14], ethanol [15], and other alcohols and polyols in AFCs have only achieved a few tens of $\mathrm{mW} / \mathrm{cm}^{2}$ as the best cell performance [8-10]. This relatively low cell performance is partly because the oxidation of alcohols and other liquid organic fuels is difficult to catalyze, even in an alkaline medium. Sodium borohydride, which is safe, non-toxic, chemically stable, and easy to transport in its dry state, is an attractive hydrogen source for fuel cells [16]. The direct borohydride fuel cell (DBFC) as a direct liquid fuel cell with a high energy density, which is $9296 \mathrm{Wh} / \mathrm{kg}$ for $\mathrm{NaBH}_{4}$, has attracted more interest recently $[17,18]$. The DBFC was first proposed in the early 1960s by Indig and Snyder [19], and Jasinski [20]. The electrochemical reactions in a DBFC employing oxygen as the oxidant are as follows.

$$
\begin{gathered}
\text { Anode: } \mathrm{BH}_{4}^{-}+8 \mathrm{OH}^{-} \rightarrow \mathrm{BO}_{2}^{-}+6 \mathrm{H}_{2} \mathrm{O}+8 \mathrm{e}^{-} \\
E^{0}=-1.24 \mathrm{~V} \text { vs. SHE }
\end{gathered}
$$

$$
\begin{gathered}
\text { Cathode: } 2 \mathrm{O}_{2}+4 \mathrm{H}_{2} \mathrm{O}+8 \mathrm{e}^{-} \rightarrow 8 \mathrm{OH}^{-} \\
E^{0}=+0.41 \mathrm{~V} \text { vs. } \mathrm{SHE} \\
\text { Overall: } \mathrm{BH}_{4}^{-}+2 \mathrm{O}_{2} \rightarrow \mathrm{BO}_{2}^{-}+2 \mathrm{H}_{2} \mathrm{O} \\
E^{0}=+1.64 \mathrm{~V} \text { vs. SHE }
\end{gathered}
$$

The electrocatalyst is a key component in the DBFC. Different metals have been studied as the anode catalyst, including Pt [21-24], Au [21,22,25-28], Ag [29-32], Os $[33,34]$, Ni [18,22,30], Pd, and $\mathrm{Cu}[22]$. Pt and Ni are more attractive than the other metals and have been proposed as the anode catalyst for DBFC by many researchers. In recent years, the interest in DBFC has been revived, as evidenced by the appearance of a number of papers on the DBFC [35-37]. Most of these works have focused on testing model DBFCs with different catalysts and different cell and/or electrode structures $[35,36]$. As catalysis is a surface effect, the catalyst needs to have the highest possible surface area. Active carbon materials are a common choice for supporting electrocatalyst particles because of their large surface areas, high electrical conductivities, and nanoporous structures [38-42]. In this study, nanoporous nickel electrodes prepared by the leaching of $\mathrm{Zn}$ was studied. It showed that the caustic leaching of $\mathrm{Zn}$ was accompanied by volume loss that led to the formation of nanopores and cracks, which yielded a highly porous catalytic surface suitable for the 
electro-oxidation of borohydride in alkaline solution.

\section{Experimental}

\subsection{Preparation}

The copper electrodes were cut and mounted in polyester while leaving a surface area of $1 \mathrm{~cm}^{2}$ for electrochemical measurements. Electrical connection was provided by a copper wire. Before electrodeposition, the electrode surface was polished with emery paper (up to 2500 grit size), then washed with distilled water, thoroughly degreased in 30 $\mathrm{wt} \% \mathrm{NaOH}$ solution for $5 \mathrm{~min}$, washed again with distilled water, dipped into $10 \mathrm{wt} \% \mathrm{H}_{2} \mathrm{SO}_{4}$ solution for $1 \mathrm{~min}$ followed by a rinse with distilled water and then immediately immersed in the bath solution. The plating baths and conditions used for the different $\mathrm{Ni}$ coatings were: (a) for the smooth $\mathrm{Ni}$ coating, these were $330 \mathrm{~g} / \mathrm{L} \mathrm{NiSO}_{4} \cdot 6 \mathrm{H}_{2} \mathrm{O}+45$ $\mathrm{g} / \mathrm{L} \mathrm{NiCl}{ }_{2} \cdot 6 \mathrm{H}_{2} \mathrm{O}+37 \mathrm{~g} / \mathrm{L} \mathrm{H}_{3} \mathrm{BO}_{3}$ (Watts bath) at $\mathrm{pH}=$ $4.0-4.5,50{ }^{\circ} \mathrm{C}$, and $50 \mathrm{~mA} / \mathrm{cm}^{2}$ for $40 \mathrm{~min}$, and (b) for the $\mathrm{Ni} / \mathrm{Zn}-\mathrm{Ni}$ coating, the co-deposition of $\mathrm{Zn}-\mathrm{Ni}$ was done on the surface of smooth $\mathrm{Ni}$ using a bath that was the same as in (a) plus $20 \mathrm{~g} / \mathrm{L} \mathrm{ZnCl}_{2}$ at the beginning of the deposition, and the electrolysis time was $30 \mathrm{~min}$ at $\mathrm{pH}=4.0-4.5,50{ }^{\circ} \mathrm{C}$ and a current density of $50 \mathrm{~mA} / \mathrm{cm}^{2}$. The surface of the $\mathrm{Cu}$ was coated with $\mathrm{Ni}$ and $\mathrm{Ni}$ (bottom layer)/Zn-Ni (top layer), respectively, so that smooth $\mathrm{Ni}$ and $\mathrm{Ni} / \mathrm{Zn}-\mathrm{Ni}$ electrodes were obtained. After deposition and rinsing with distilled water, the $\mathrm{Ni} / \mathrm{Zn}-\mathrm{Ni}$ electrode was immersed in $30 \mathrm{wt} \%$ $\mathrm{NaOH}$ solution at room temperature for $48 \mathrm{~h}$ to get the zinc metal to dissolve to obtain a more porous electrode. After the leaching, the working electrode was held at $100 \mathrm{~mA} / \mathrm{cm}^{2}$ cathodic current density in $1 \mathrm{~mol} / \mathrm{L} \mathrm{KOH}$ solution for 30 min to reduce the oxide film on the electrode surface and remove corrosion products from the pores of the coating and to obtain a reproducible electrode [43].

\subsection{Characterization}

The bulk composition of the coatings and the loadings on the smooth nickel and Ni/Zn-Ni electrodes before and after leaching were determined by atomic absorption spectroscopy (AAS, NovAA 400-Analytikjena). The surface compositions of the coatings before and after leaching were determined by energy dispersive X-ray (EDX) analysis. Scanning electron microscopy (SEM) images were taken using a Philips Model XL30 instrument.

\subsection{Electrochemical test}

The electrochemical studies were carried out in a conventional electrochemical cell. All the solutions were purged with purified nitrogen for 10 min before the measurement. A standard three-electrode cell arrangement was used in all experiments. A platinum sheet with a geometric area of about $20 \mathrm{~cm}^{2}$ was used as the counter electrode. All potentials were measured with respect to a commercial saturated calomel electrode (SCE). The catalytic activity of the electrodes was measured by cyclic voltammetry $(\mathrm{CV})$ and electrochemical impedance spectroscopy (EIS). The electrochemical experiments were carried out using a Princeton Applied Research, EG\&G PARSTAT 2263 Advanced Electrochemical system ran by the PowerSuite software. The r.m.s amplitude of the modulation potential for the EIS measurements was $10 \mathrm{mV}$. The frequency range was 100 $\mathrm{kHz}$ to $10 \mathrm{mHz}$. All the chemicals were analytical grade and used as received. For each experiment, a freshly prepared electrode and solution were used.

\section{Results and discussion}

\subsection{Characterization results}

The bulk composition and metal loading of the electrodes were characterized by AAS of a solution obtained by the complete dissolution of the deposits in diluted $\mathrm{HNO}_{3}$ solution. The percentage metal ratios determined are given in Table 1. The chemical composition analysis by AAS revealed that the dezincification process left a surface rich in nickel. The $\mathrm{Zn}$ content was decreased from $32.05 \mathrm{wt} \%$ to $2.29 \mathrm{wt} \%$ after the selective dissolution. The AAS analysis for the smooth nickel coating was $26.00 \mathrm{mg} / \mathrm{cm}^{2}$. The loading amounts of $\mathrm{Ni}$ and $\mathrm{Zn}$ on the $\mathrm{Ni} / \mathrm{Zn}-\mathrm{Ni}$ electrode before leaching were 27.40 and $12.92 \mathrm{mg} / \mathrm{cm}^{2}$, respectively, while after leaching, the loadings of $\mathrm{Ni}$ and $\mathrm{Zn}$ were 21.38 and $0.50 \mathrm{mg} / \mathrm{cm}^{2}$, respectively. The surface compositions of the deposit before and after leaching were analyzed by EDX analysis. The results are shown in Table 1 . The Ni content of the bulk composition (AAS) was higher than that of the surface (EDX) and the $\mathrm{Zn}$ content of the bulk composition was lower than that of the surface. These results suggested that the $\mathrm{Ni} / \mathrm{Zn}-\mathrm{Ni}$ deposit did not have a homogenous chemical composition and the chemical composition of the deposit changed as the film got thicker. The AAS and EDX analysis results revealed that the large amounts of $\mathrm{Zn}$ dissolved from the deposit led to pore and crack formation,

Table 1 Bulk composition (determined by AAS) and surface composition (determined by EDX) of the coated deposits before and after leaching

\begin{tabular}{lccccc}
\hline \multirow{2}{*}{ Leaching } & \multicolumn{2}{c}{ Bulk composition (wt\%) } & & \multicolumn{2}{c}{ Surface composition (wt\%) } \\
\cline { 2 - 3 } \cline { 5 - 6 } & $\mathrm{Ni}$ & $\mathrm{Zn}$ & & $\mathrm{Ni}$ & $\mathrm{Zn}$ \\
\hline Before & 67.95 & 32.05 & & 15.42 & 84.58 \\
After & 97.71 & 2.29 & & 59.51 & 40.49 \\
\hline
\end{tabular}




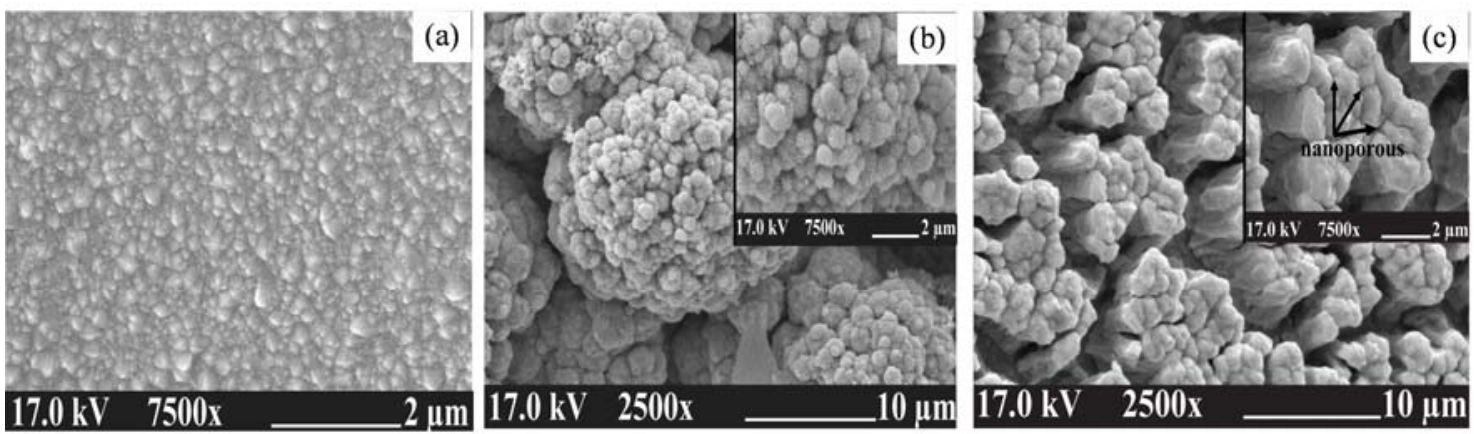

Fig. 1. SEM images of smooth nickel surface (a) and Ni/Zn-Ni surface before (b) and after (c) treatment with $30 \% \mathrm{NaOH}$ solution.

which yielded a highly porous surface suitable for borohydride electro-oxidation.

The SEM images in Fig. 1 showed significant differences in the morphology of the two different coatings. The smooth Ni electrode showed a relatively homogeneous surface with little roughness, which can be considered a quasi-two dimensional surface (Fig. 1(a)). The SEM images of the $\mathrm{Ni} / \mathrm{Zn}-\mathrm{Ni}$ electrode before and after leaching are shown in Fig. 1(b) and 1(c), respectively. The deposit had a porous structure before leaching. Moreover, the porosity of surface was increased and more cracks and nanopores appeared after the leaching of $\mathrm{Zn}$ from the deposit, which gave a high surface area for borohydride electro-oxidation (Fig. 1(c)).

\subsection{Cyclic voltammetry}

Figure 2 shows the $\mathrm{CV}$ voltammograms of the smooth nickel electrode and nanoporous $\mathrm{Ni} / \mathrm{Zn}-\mathrm{Ni}$ electrode in 1 $\mathrm{mol} / \mathrm{L} \mathrm{NaOH}$ solution recorded at a potential sweep rate of $10 \mathrm{mV} / \mathrm{s}$. During the anodic sweep, both electrodes exhibited only one anodic peak at 0.38 and $0.49 \mathrm{~V}$, respectively. In the reverse sweep, only one cathodic peak was detected, which was assigned to the $\mathrm{Ni}^{2+} / \mathrm{Ni}^{3+}$ redox process. Com-

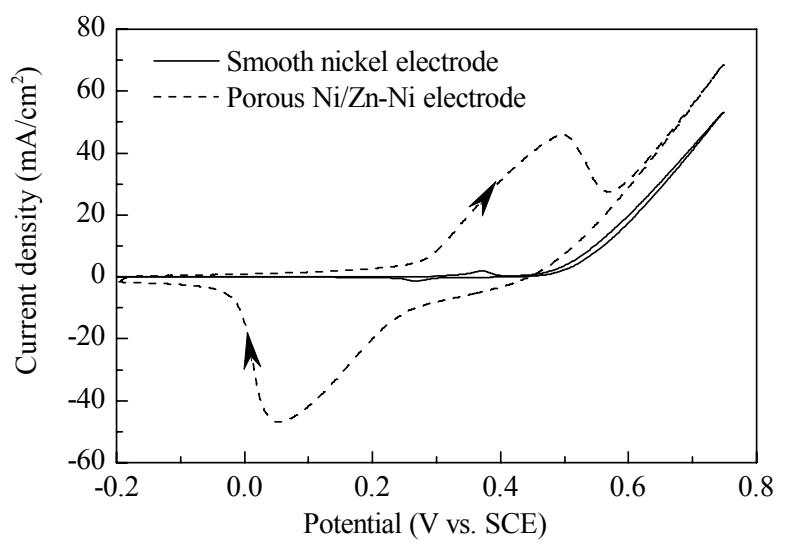

Fig. 2. Cyclic voltammograms of the smooth nickel electrode and leached $\mathrm{Ni} / \mathrm{Zn}-\mathrm{Ni}$ electrode in $1 \mathrm{~mol} / \mathrm{L} \mathrm{NaOH}$ solution at a potential sweep rate of $10 \mathrm{mV} / \mathrm{s}$. pared to the smooth nickel electrode, the current density on the nanoporous $\mathrm{Ni} / \mathrm{Zn}-\mathrm{Ni}$ electrode was higher $(45.5$ $\mathrm{mA} / \mathrm{cm}^{2}$ ), which can be attributed to the increase in surface area and changes in surface features.

Figure 3 shows the cyclic voltammograms of the electro-oxidation of borohydride on the nanoporous $\mathrm{Ni} / \mathrm{Zn}-\mathrm{Ni}$ electrode in the absence and presence of borohydride in 1 $\mathrm{mol} / \mathrm{L} \mathrm{NaOH}$ solution. An increase in the anodic peak current for peak $a_{1}$ followed by the appearance of a new peak $\left(\mathrm{a}_{2}\right)$ at a more positive potential $(0.635 \mathrm{~V}$ vs. SCE $)$ were the main effects observed on the addition of $0.02 \mathrm{~mol} / \mathrm{L}$ borohydride to the electrolyte. The $\mathrm{a}_{1}$ peak became ill-defined and was hard to distinguish in the presence of borohydride. Moreover, $E_{\mathrm{pa} 2}$ was higher than $E_{\mathrm{pa} 1}$, which indicated that the active species needed for borohydride oxidation were mainly generated at a higher anodic potential. The appearance of the new anodic peak $\left(a_{2}\right)$ led to the conclusion that borohydride oxidation took place after the oxidation of $\mathrm{Ni}(\mathrm{OH})_{2}$ to $\mathrm{NiOOH}[44,45]$. The $\mathrm{Ni}^{2+} / \mathrm{Ni}^{3+}$ redox couple acts as a catalyst for the oxidation of borohydride in basic solutions. Therefore, for the $\mathrm{Ni} / \mathrm{Zn}-\mathrm{Ni}$ electrode, peak $\mathrm{a}_{1}$ was due to the $\alpha-\mathrm{Ni}(\mathrm{OH})_{2} / \mathrm{NiOOH}$ redox couple and peak $\mathrm{a}_{2}$ was assigned to the electro-oxidation of borohydride.

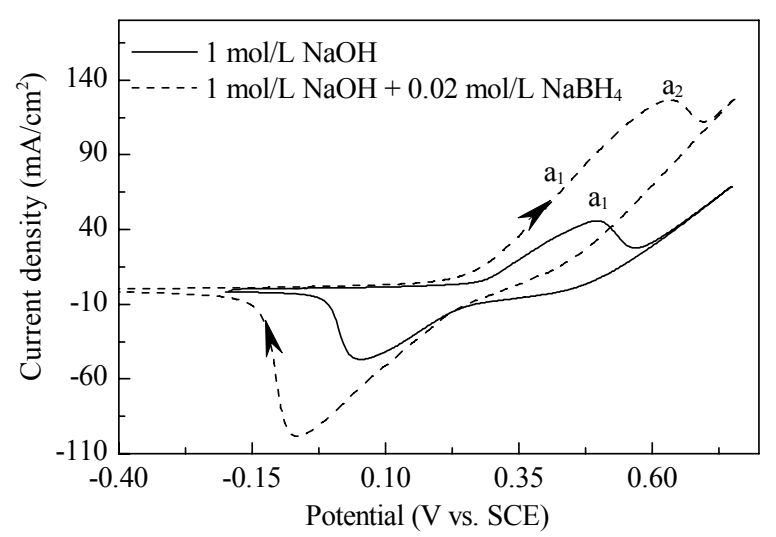

Fig. 3. Cyclic voltammograms of leached $\mathrm{Ni} / \mathrm{Zn}-\mathrm{Ni}$ electrode in the absence and the presence of $0.02 \mathrm{~mol} / \mathrm{L}$ borohydride in $1 \mathrm{~mol} / \mathrm{L} \mathrm{NaOH}$ solution at a potential sweep rate of $10 \mathrm{mV} / \mathrm{s}$. 
The electro-catalytic activity of the leached Ni/Zn-Ni electrode for borohydride oxidation was evaluated by cyclic voltammetry and compared to that of the smooth nickel electrode. Figure 4 shows that the current density of the $\mathrm{Ni} / \mathrm{Zn}-\mathrm{Ni}$ electrode was much higher than that of the smooth nickel electrode. For example, at the potential of peak $a_{2}$, the Ni/Zn-Ni electrode showed a current density of 125.8 $\mathrm{mA} / \mathrm{cm}^{2}$, which was nearly 21 times higher than that of the smooth nickel electrode $\left(6.0 \mathrm{~mA} / \mathrm{cm}^{2}\right)$. In addition, Fig. 4 shows that the onset oxidation potential of the $\alpha-\mathrm{Ni}(\mathrm{OH})_{2} / \mathrm{NiOOH}$ redox couple on the leached $\mathrm{Ni} / \mathrm{Zn}-\mathrm{Ni}$ electrode was lower than that with the smooth nickel electrode. Generally, the leached Ni/Zn-Ni electrode showed significantly higher electro-catalytic activity for borohydride oxidation. The higher activity of the leached $\mathrm{Ni} / \mathrm{Zn}-\mathrm{Ni}$ electrode was due to the high surface area that was formed after the selective dissolution of $\mathrm{Zn}$ from the surface, as substantiated by the SEM images (Fig. 1(c)).

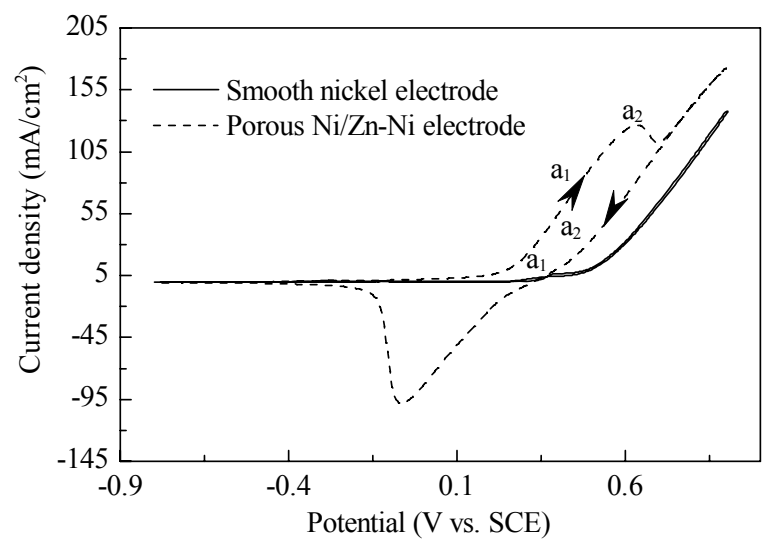

Fig. 4. CVs of smooth nickel electrode and leached $\mathrm{Ni} / \mathrm{Zn}-\mathrm{Ni}$ electrode in $0.02 \mathrm{~mol} / \mathrm{L}$ borohydride and $1 \mathrm{~mol} / \mathrm{L} \mathrm{NaOH}$ solution at a potential sweep rate of $10 \mathrm{mV} / \mathrm{s}$.

Table 2 presents a comparison of the peak current $\left(i_{\mathrm{p}}\right)$ during borohydride oxidation on the leached $\mathrm{Ni} / \mathrm{Ni}-\mathrm{Zn}$ electrode with those of different electrodes in the literatures [46-51]. It is evident from Table 2 that the peak current density of the leached $\mathrm{Ni} / \mathrm{Ni}-\mathrm{Zn}$ electrode was higher than those of the other different electrodes. In other word, among these electrodes, the leached $\mathrm{Ni} / \mathrm{Ni}-\mathrm{Zn}$ electrode has the best electro-catalytic activity for borohydride electro-oxidation in alkaline medium. The enhanced electro-catalytic activity of the $\mathrm{Ni} / \mathrm{Zn}-\mathrm{Ni}$ electrode can be attributed to the increase in surface area.

The influence of the scan rate on the $\mathrm{CV}$ behavior of the leached $\mathrm{Ni} / \mathrm{Zn}-\mathrm{Ni}$ electrode in $1 \mathrm{~mol} / \mathrm{L} \mathrm{NaOH} / 0.02 \mathrm{~mol} / \mathrm{L}$ borohydride is shown in Fig. 5 . This shows the CVs of the leached $\mathrm{Ni} / \mathrm{Zn}-\mathrm{Ni}$ electrode from -0.90 to $0.85 \mathrm{~V}$ at different potential sweep rates from 1 to $20 \mathrm{mV} / \mathrm{s}$ in $1 \mathrm{~mol} / \mathrm{L} \mathrm{NaOH}+$ $0.02 \mathrm{~mol} / \mathrm{L}$ borohydride solution. As the scan rate increased, the anodic peak potential was shifted to more positive values and the cathodic peak potential was shifted in a slightly negative direction.

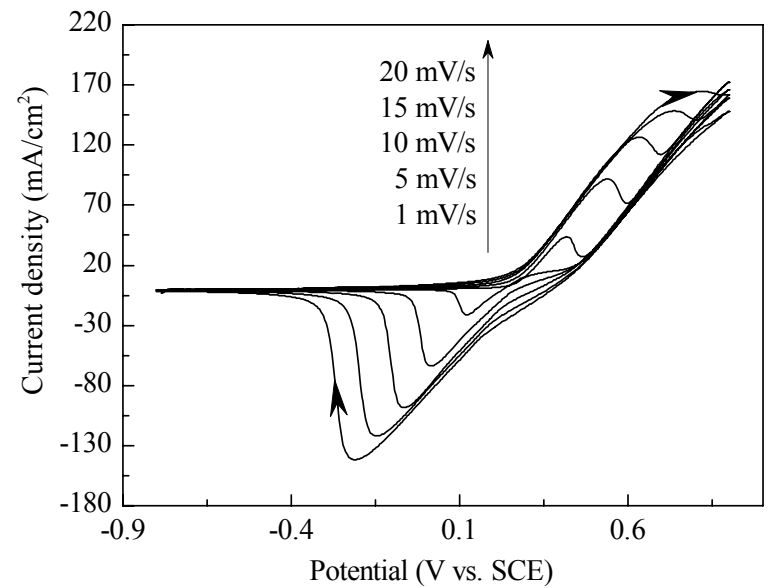

Fig. 5. Cyclic voltammograms obtained in $1 \mathrm{~mol} / \mathrm{L} \mathrm{NaOH}+0.02$ $\mathrm{mol} / \mathrm{L}$ borohydride for the leached $\mathrm{Ni} / \mathrm{Zn}-\mathrm{Ni}$ electrode at various scan rates.

The plot of the CV peak currents $I_{\mathrm{pa}}$ against the square root of the voltage scan rate $\left(v^{1 / 2}\right)$ gave a linear relationship $\left(R^{2}=0.9955\right.$, Fig. 6). In semi-infinite diffusion-controlled cyclic voltammetry in liquid electrolytes, $I_{\mathrm{pa}}$ against $v^{1 / 2}$ gives a linear relationship for a kinetically simple redox reaction. Thus, the linear relationship between $I_{\mathrm{pa}}$ and $v^{1 / 2}$ demonstrated that the electrochemical reaction of the formation $\mathrm{NiOOH}$ from $\mathrm{Ni}(\mathrm{OH})_{2}$ was a diffusion-controlled process.

Table 2 Composition of the peak current density $\left(i_{\mathrm{p}}\right)$ during the oxidation of $\mathrm{NaBH}_{4}$ on leached Ni/Ni-Zn electrode and different electrodes

\begin{tabular}{|c|c|c|c|c|}
\hline Electrode & Medium & Scan rate $(\mathrm{mV} / \mathrm{s})$ & $i_{\mathrm{p}} /\left(\mathrm{mA} / \mathrm{cm}^{2}\right)$ & Ref. \\
\hline Ni deposited carbon fiber & $0.8 \mathrm{mmol} / \mathrm{L} \mathrm{NaBH}_{4}+2 \mathrm{~mol} / \mathrm{L} \mathrm{KOH}$ & 50 & 56.0 & {$[46]$} \\
\hline Nickel & $0.05 \mathrm{~mol} / \mathrm{L} \mathrm{NaBH}_{4}+1 \mathrm{~mol} / \mathrm{L} \mathrm{NaOH}$ & 10 & 4.0 & [47] \\
\hline $\mathrm{Ni} / \mathrm{C}$ & $0.2 \mathrm{~mol} / \mathrm{L} \mathrm{NaBH}_{4}+2 \mathrm{~mol} / \mathrm{L} \mathrm{NaOH}$ & 50 & 18.0 & [48] \\
\hline $\mathrm{Ni}_{37}-\mathrm{Pt}_{3} / \mathrm{C}$ & $0.2 \mathrm{~mol} / \mathrm{L} \mathrm{NaBH}_{4}+2 \mathrm{~mol} / \mathrm{L} \mathrm{NaOH}$ & 50 & 26.0 & [48] \\
\hline $\mathrm{Ag}$ & $0.001 \mathrm{~mol} / \mathrm{L} \mathrm{NaBH}_{4}+0.1 \mathrm{~mol} / \mathrm{L} \mathrm{NaOH}$ & 100 & 2.5 & [49] \\
\hline $\mathrm{Au}$ & $0.00125 \mathrm{~mol} / \mathrm{L} \mathrm{NaBH}_{4}+0.2 \mathrm{~mol} / \mathrm{L} \mathrm{KOH}$ & 100 & 0.4 & {$[50]$} \\
\hline Nanoporous gold wire array & $0.02 \mathrm{~mol} / \mathrm{L} \mathrm{NaBH}_{4}+1 \mathrm{~mol} / \mathrm{L} \mathrm{NaOH}$ & 10 & 73.6 & {$[51]$} \\
\hline Leached Ni/Zn-Ni & $0.02 \mathrm{~mol} / \mathrm{L} \mathrm{NaBH}_{4}+1 \mathrm{~mol} / \mathrm{L} \mathrm{NaOH}$ & 10 & 125.8 & this work \\
\hline
\end{tabular}




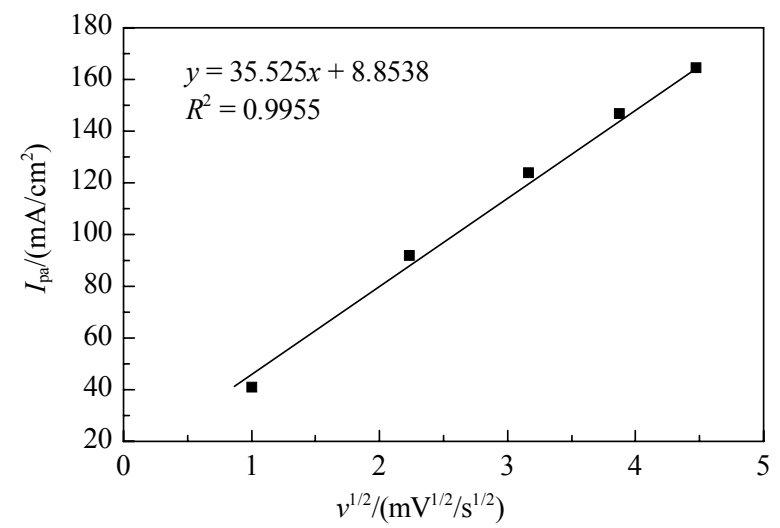

Fig. 6. Plot of anodic current density versus $v^{1 / 2}$ in $1 \mathrm{~mol} / \mathrm{L} \mathrm{NaOH}+$ $0.02 \mathrm{~mol} / \mathrm{L}$ borohydride for the leached $\mathrm{Ni} / \mathrm{Zn}-\mathrm{Ni}$ electrode.

Figure 7 shows typical $\mathrm{CVs}$ of the $\mathrm{Ni} / \mathrm{Zn}-\mathrm{Ni}$ electrode from -0.90 to $0.85 \mathrm{~V}$ at the scan rate of $5 \mathrm{mV} / \mathrm{s}$ in $1 \mathrm{~mol} / \mathrm{L}$ $\mathrm{NaOH}$ solution as the concentration of borohydride was changed from 0.02 to $0.06 \mathrm{~mol} / \mathrm{L}$. As the borohydride concentration was increased, the current density of the anodic peak $a_{2}$ increased. This further indicated that the anodic peak $a_{2}$ was due to the electrooxidation of borohydride. It seems from Fig. 7 that only one anodic peak $a_{2}$ appeared in the presence of borohydride. This was because the current density of the anodic peak $a_{2}$ was so large that the anodic peak $a_{1}$ became ill-defined.

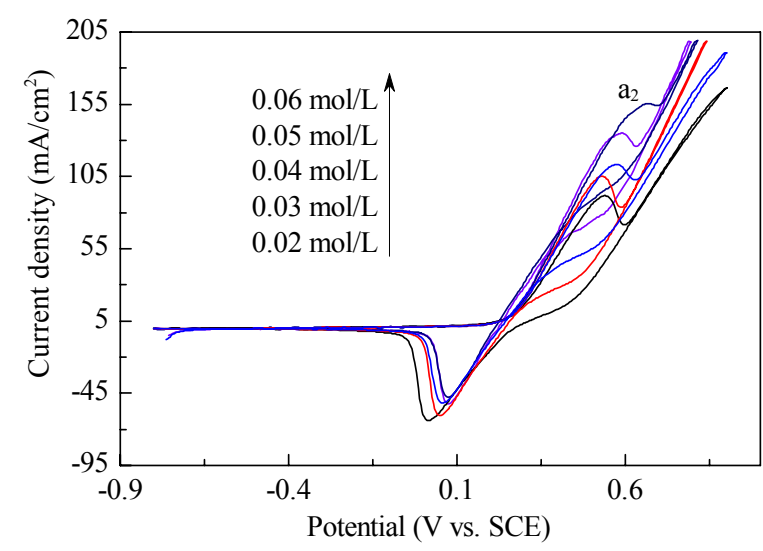

Fig. 7. Cyclic voltammograms of the leached $\mathrm{Ni} / \mathrm{Zn}-\mathrm{Ni}$ electrode from -0.90 to $0.85 \mathrm{~V}$ at the scan rate of $5 \mathrm{mV} / \mathrm{s}$ in $1 \mathrm{~mol} / \mathrm{L} \mathrm{NaOH}$ solution with the various concentrations of borohydride.

According to Aytaç et al. [46], the electrochemical oxidation of $\mathrm{NaBH}_{4}$ at $\mathrm{Ni}$ electrodes is

$$
\begin{gathered}
\mathrm{Ni}+2 \mathrm{OH}^{-} \rightarrow \mathrm{Ni}(\mathrm{OH})_{2}+2 \mathrm{e}^{-} \\
\mathrm{Ni}(\mathrm{OH})_{2}+\mathrm{OH}^{-} \rightarrow \mathrm{NiOOH}+\mathrm{H}_{2} \mathrm{O}+\mathrm{e}^{-} \\
\mathrm{NiOOH}+\mathrm{NaBH}_{4} \rightarrow \mathrm{Ni}(\mathrm{OH})_{2}+\text { oxidation products of } \\
\mathrm{NaBH}_{4}
\end{gathered}
$$

Active $\mathrm{NiOOH}$ formed during the positive potential scan is consumed by reaction (6). Subsequently, the $\mathrm{Ni}(\mathrm{OH})_{2}$ formed in reaction (6) is oxidized to $\mathrm{NiOOH}$ during the anodic potential sweep. This results in an increase in oxidation current in the presence of $\mathrm{NaBH}_{4}$.

Generally, the total anodic reaction of $\mathrm{BH}_{4}^{-}$on the $\mathrm{Ni}$ electrode can be expressed as [18]

$$
\mathrm{BH}_{4}^{-}+4 \mathrm{OH}^{-} \rightarrow \mathrm{BO}_{2}^{-}+2 \mathrm{H}_{2} \mathrm{O}+2 \mathrm{H}_{2}+4 \mathrm{e}^{-}
$$

At the $\mathrm{Ni} / \mathrm{Zn}-\mathrm{Ni}$ electrode, the oxidation of $\mathrm{NaBH}_{4}$ gave a typical electro-catalytic response. The anodic current in the positive sweep was proportional to the amounts of $\mathrm{NaBH}_{4}$ (Fig. 8) and an increase in the amounts of $\mathrm{NaBH}_{4}$ caused a linear enhancement of the anodic current. So, there was electro-oxidation of $\mathrm{NaBH}_{4}$ on the $\mathrm{Ni} / \mathrm{Zn}-\mathrm{Ni}$ electrode. It can be seen from Fig. 8 that the current density $I_{\mathrm{pa}}$ was linearly proportional to the concentration of borohydride. The linear dependence of $I_{\mathrm{pa}}$ on borohydride concentrations indicated that the $\mathrm{Ni} / \mathrm{Zn}-\mathrm{Ni}$ electrode may be used as anperometric sensor for borohydride detection.

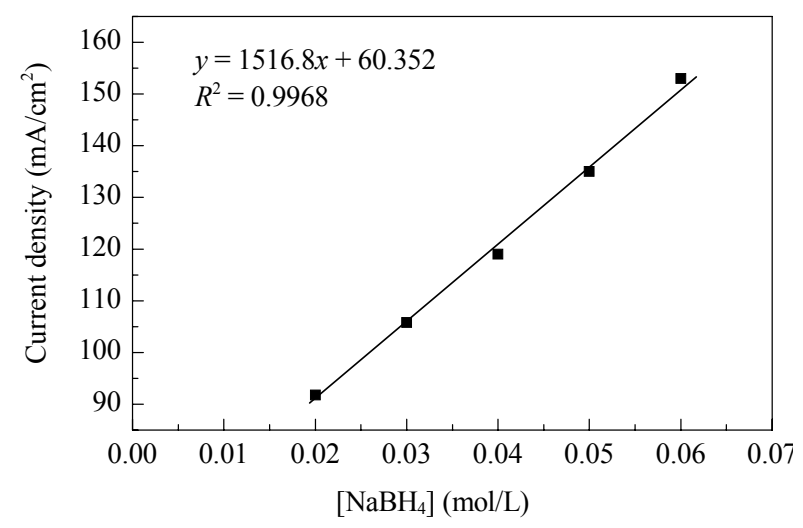

Fig. 8. Anodic current density versus borohydride concentration for the leached Ni/Zn-Ni electrode.

\subsection{Electrochemical impedance spectroscopy results}

Figure 9 presents the equivalent circuits and Nyquist diagrams of the smooth nickel and leached $\mathrm{Ni} / \mathrm{Zn}-\mathrm{Ni}$ electrodes recorded at the potential of $0.38 \mathrm{~V}$ vs. SCE, both in the absence of borohydride in $1 \mathrm{~mol} / \mathrm{L} \mathrm{NaOH}$ solution. In order to fit the impedance spectra obtained for the Ni/Zn-Ni electrodes, a two constant phase element (CPE's) serial model was applied (shown in the inset of the Nyquist diagram in Fig. 9). This consisted of the solution resistance, $R_{\mathrm{s}}$, in series with two parallel $Z_{\mathrm{CPE}}-R$ elements (2CPE model) $[52,53]$. This was used for the analysis of the EIS results of the electro-oxidation of $\mathrm{NaBH}_{4}$ at $\mathrm{Ni} / \mathrm{Zn}-\mathrm{Ni}$ electrodes. The $Z_{\mathrm{CPE}}$ was defined by two parameters, $T$ and $\Phi$, in the equation for the impedance [54]:

$$
Z_{\mathrm{CPE}}=1 / T(j \omega)^{\Phi}
$$

where CPE is the constant phase element, $T$ is the capacitance parameter, and $\Phi$ is the phase shift which can be explained by the degree of surface inhomogeneity. In this 


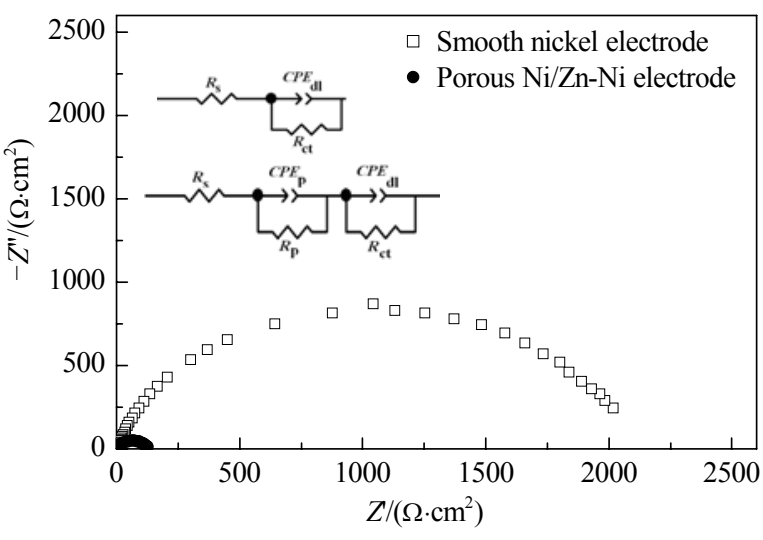

Fig. 9. Equivalent circuits and Nyquist diagrams of the smooth nickel and leached $\mathrm{Ni} / \mathrm{Zn}-\mathrm{Ni}$ electrodes in $1 \mathrm{~mol} / \mathrm{L} \mathrm{NaOH}$ solution at the potential $0.38 \mathrm{~V}$ vs. SCE.

model, the high frequency time constant, which is independent of the potential and is described by $R_{\mathrm{p}}$ and $C P E_{\mathrm{p}}$ connected in parallel, indicated electrode porosity, while the potential dependent time constant gave the kinetics of the electro-oxidation of borohydride $\left(R_{\mathrm{ct}}\right.$ and $C P E_{\mathrm{dl}}$ connected in parallel). The capacitance parameter $T_{\mathrm{dl}}$ gave the average double layer capacitance $C_{\mathrm{dl}}$ by the relationship

$$
C_{\mathrm{dl}}=\left\{T_{\mathrm{dl}} /\left[\left(R_{\mathrm{s}}+R_{\mathrm{p}}\right)^{-1}+R_{\mathrm{ct}}^{-1}\right]^{(1-\Phi)}\right\}^{1 / \Phi}
$$

where $\Phi$ represents a factor of homogeneity [53]. In the case of the smooth nickel electrode, the capacitance parameter $T_{\mathrm{dl}}$ was related to the average double layer capacitance $C_{\mathrm{dl}}$ by a slightly different relationship [53]:

$$
C_{\mathrm{dl}}=\left\{T_{\mathrm{d} l} /\left[R_{\mathrm{s}}^{-1}+R_{\mathrm{ct}}{ }^{-1}\right]^{(1-\Phi)}\right\}^{1 / \Phi}
$$

Because its Nyquist diagrams exhibited only one semicircle. The equivalent circuit includes the CPE in parallel with the charge transfer resistance $R_{\mathrm{ct}}$ (shown in the inset of the Nyquist diagram in Fig. 9). The values of the charge transfer resistance, double layer capacitance, total surface area, and roughness factor for the two electrodes are presented in Table 3. The capacitance, $C_{\mathrm{dl}}$, determined for the $\mathrm{Ni} / \mathrm{Zn}-\mathrm{Ni}$ electrode was two orders of magnitude larger than that for the smooth nickel. Taking the average double layer capacitance $\left(C_{\mathrm{dl}}\right)$ of a smooth metal surface as $20 \mu \mathrm{F} / \mathrm{cm}^{2}$ $[55,56]$, the total surface area was calculated as $A_{\text {real }}=C_{\mathrm{dl}} / 20$ $\left(\mathrm{cm}^{2}\right)$ [57]. The roughness factor, the total-to-geometrical surface area ratio, was calculated as $R_{\mathrm{f}}=A_{\text {real }} / A_{\text {geometric }}$. It can be seen from Table 3 that the smooth Ni electrode had the lower total surface area and roughness factor, while the $\mathrm{Ni} / \mathrm{Zn}-\mathrm{Ni}$ electrode had the higher total surface area and roughness (also compare with Fig. 1). This was the reason why the catalytic activity of the $\mathrm{Ni} / \mathrm{Zn}-\mathrm{Ni}$ electrode was higher.

Figure 10 shows the equivalent circuit and Nyquist plots of the impedance of the $\mathrm{Ni} / \mathrm{Zn}-\mathrm{Ni}$ electrode for borohydride electro-oxidation at different potentials in $1 \mathrm{~mol} / \mathrm{L} \mathrm{NaOH}+$ $0.02 \mathrm{~mol} / \mathrm{L}$ borohydride solution. The Nyquist plots in Fig. 10 also showed the porosity of the electrode surfaces. Typi-
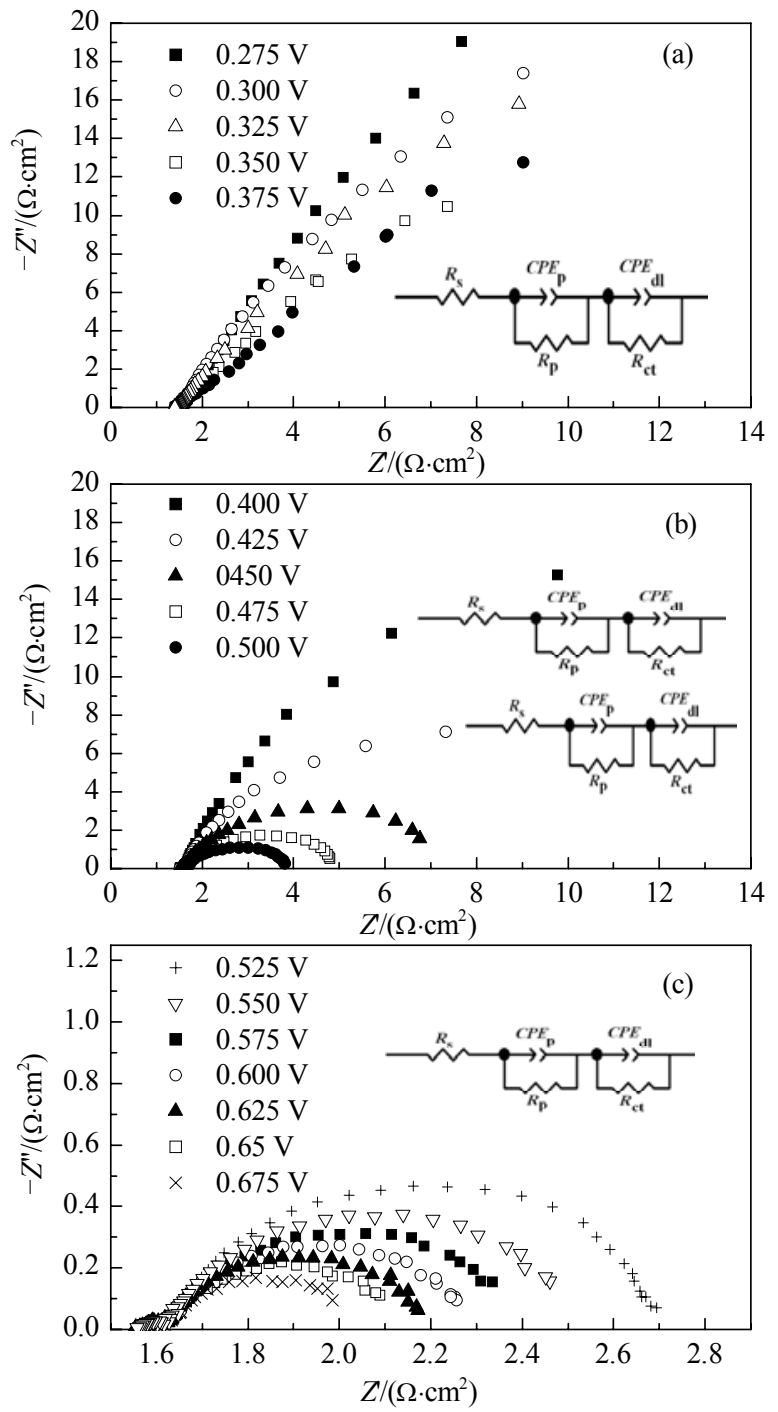

Fig. 10. Equivalent circuits and experimental Nyquist diagrams as a function of applied potential for borohydride electro-oxidation on the leached $\mathrm{Ni} / \mathrm{Zn}-\mathrm{Ni}$ electrode in $1 \mathrm{~mol} / \mathrm{L} \mathrm{NaOH}+0.02 \mathrm{~mol} / \mathrm{L}$ borohydride aqueous solutions for potential between 0.275 and $0.375 \mathrm{~V}$ vs. SCE (a), potential between 0.4 and $0.5 \mathrm{~V}$ vs. SCE (b), and potential between 0.525 and $0.675 \mathrm{~V}$ vs. SCE (c).

Table 3 Double layer capacitance, surface area, and surface roughness calculated from the EIS data of Fig. 9

\begin{tabular}{lccccccccc}
\hline Electrode & $\begin{array}{c}R_{\mathrm{s}} / \\
\left(\Omega \cdot \mathrm{cm}^{2}\right)\end{array}$ & $\begin{array}{c}T_{\mathrm{P}} / \\
\left(\Omega^{-1} \cdot \mathrm{cm}^{-2} \cdot \mathrm{s}^{\Phi}\right)\end{array}$ & $\begin{array}{c}R_{\mathrm{P}} / \\
\left(\Omega \cdot \mathrm{cm}^{2}\right)\end{array}$ & $\begin{array}{c}\Phi_{\mathrm{p}} \\
\left(\Omega^{-1} \cdot \mathrm{cm}^{-2} \cdot \mathrm{s}^{\Phi}\right)\end{array}$ & $\begin{array}{c}R_{\mathrm{ct}} / \\
\left(\Omega \cdot \mathrm{cm}^{2}\right)\end{array}$ & $\begin{array}{c}T_{\mathrm{dl}} \\
A_{\mathrm{dl}} / \\
\left(\mu \mathrm{F} / \mathrm{cm}^{2}\right)\end{array}$ \\
\hline Smooth Ni & 4.66 & - & - & - & 0.0003405 & 2090.0 & 0.860 & $\begin{array}{c}A_{\text {real }} / \\
\mathrm{cm}^{2}\end{array}$ \\
Porous Ni/Zn-Ni & 4.06 & 0.15 & 26.85 & 0.69 & 0.0068580 & 103.5 & $\begin{array}{c}5.959 \\
R_{\mathrm{f}}\end{array}$ \\
\hline
\end{tabular}


Table 4 Equivalent circuit parameters of electro-oxidation of $0.02 \mathrm{~mol} / \mathrm{L}$ borohydride on the leached Ni/Zn-Ni electrode in $1 \mathrm{~mol} / \mathrm{L} \mathrm{NaOH}$ solution obtained from Fig. 10

\begin{tabular}{|c|c|c|c|c|c|c|c|c|c|}
\hline$E / \mathrm{V}$ & $R_{\mathrm{s}} /\left(\Omega \cdot \mathrm{cm}^{2}\right)$ & $T_{\mathrm{P}} /\left(\Omega^{-1} \cdot \mathrm{cm}^{-2} \cdot \mathrm{s}^{\Phi}\right)$ & $R_{\mathrm{P}} /\left(\Omega \cdot \mathrm{cm}^{2}\right)$ & $\Phi_{\mathrm{p}}$ & $T_{\mathrm{dl}} /\left(\Omega^{-1} \cdot \mathrm{cm}^{-2} \cdot \mathrm{s}^{\Phi}\right)$ & $R_{\mathrm{ct}} /\left(\Omega \cdot \mathrm{cm}^{2}\right)$ & $\Phi_{\mathrm{dl}}$ & $C_{\mathrm{dl}} /\left(\mu \mathrm{F} / \mathrm{cm}^{2}\right)$ & Error $(\%)$ \\
\hline 0.275 & 0.93 & 0.7210 & 0.5608 & 0.825 & 0.3340 & 135.800 & 0.836 & 290704.12 & 1.58 \\
\hline 0.300 & 1.54 & 0.6640 & 6.8200 & 0.701 & 0.4500 & 108.700 & 1.000 & 450000.00 & 1.44 \\
\hline 0.325 & 1.38 & 4.5420 & 4.9000 & 0.317 & 1.1820 & 52.660 & 0.970 & 1253225.74 & 2.35 \\
\hline 0.350 & 1.47 & 3.3300 & 6.2300 & 0.182 & 0.6248 & 37.340 & 0.969 & 653073.75 & 1.57 \\
\hline 0.375 & 1.41 & 1.9900 & 1.6700 & 0.560 & 1.8690 & 21.520 & 1.000 & 1869000.00 & 4.65 \\
\hline 0.400 & 1.45 & 0.7203 & 1.1780 & 0.998 & 1.1750 & 21.090 & 1.000 & 1175000.00 & 4.85 \\
\hline 0.425 & 1.50 & 2.1300 & 0.8700 & 0.306 & 0.5780 & 13.860 & 1.000 & 578000.00 & 2.73 \\
\hline 0.450 & 1.48 & 1.1320 & 0.3660 & 0.348 & 0.5270 & 5.920 & 1.000 & 527000.00 & 2.84 \\
\hline 0.475 & 1.52 & 0.7860 & 0.2520 & 0.452 & 0.4880 & 3.230 & 1.000 & 488000.00 & 1.88 \\
\hline 0.500 & 1.51 & 1.1280 & 0.3140 & 0.385 & 0.5010 & 2.080 & 1.000 & 501000.00 & 0.90 \\
\hline 0.525 & 1.53 & 0.8560 & 0.1860 & 0.401 & 0.5617 & 0.980 & 0.955 & 534623.85 & 0.70 \\
\hline 0.550 & 1.52 & 0.7690 & 0.1720 & 0.558 & 0.5142 & 0.939 & 0.839 & 238790.59 & 1.40 \\
\hline 0.575 & 1.55 & 0.6320 & 0.1380 & 0.444 & 0.5056 & 0.686 & 0.926 & 452091.20 & 0.53 \\
\hline 0.600 & 1.56 & 0.1510 & 0.0780 & 0.688 & 0.4622 & 0.649 & 0.880 & 421604.31 & 0.51 \\
\hline 0.625 & 1.56 & 0.1608 & 0.0730 & 0.694 & 0.4650 & 0.564 & 0.873 & 366587.88 & 0.50 \\
\hline 0.650 & 1.57 & 0.0375 & 0.0460 & 0.942 & 0.4614 & 0.531 & 0.835 & 330365.33 & 0.60 \\
\hline 0.675 & 1.57 & 0.0730 & 0.0520 & 0.812 & 0.4806 & 0.423 & 0.828 & 328977.97 & 0.60 \\
\hline
\end{tabular}

cally, Nyquist plots of nanoporous electrodes show either a line with a slope of $45^{\circ}$ or a semicircle at high frequencies followed by a semicircle at low frequencies [58,59]. The two constant phase element (2CPE) model of Chen and Lasia [60] can be used to explain the impedance results of the $\mathrm{Ni} / \mathrm{Zn}-\mathrm{Ni}$ electrode. The impedance data from borohydride electro-oxidation on the $\mathrm{Ni} / \mathrm{Zn}-\mathrm{Ni}$ electrode were interpreted using the equivalent electric circuit for nanoporous electrodes [60] in the inset of the Nyquist diagrams in Figs. 9 and 10. The charge transfer resistance decrease with increasing potential indicated a faster reaction at higher potentials. In the potential below $0.375 \mathrm{~V}$ vs. SCE, large depressed capacitive semicircles were observed (Fig. 10(a)), which indicated a slow rate of borohydride electro-oxidation. In the potential between 0.4 and $0.5 \mathrm{~V}$ (Fig. 10(b)), the semicircle diameters decreased sharply with increasing potential. In Fig. 10, the impedance data at $0.275-0.500 \mathrm{~V}$ were higher than those at $0.525-0.675 \mathrm{~V}$ because the borohydride electro-oxidation reaction commenced at potentials higher than $0.5 \mathrm{~V}$. These observations were consistent with the $\mathrm{CV}$ results.

Table 4 shows the values of the equivalent circuit elements obtained by fitting the experimental results. In the whole overpotential range, the very low resistance $R_{\mathrm{p}}$ and values of the $C P E_{\mathrm{p}}$ exponent $\Phi_{\mathrm{p}}$ can be explained by pore resistance and diffusion in the pores of the deposit [61]. However, the $C P E_{\mathrm{dl}}$ exponent $\Phi_{\mathrm{dl}}$ values were much closer to 1 . Also the mean error was smaller than $5 \%$, indicating a good fit of the experimental data. Generally, the presence of borohydride speeds up the oxidation of $\mathrm{Ni}(\mathrm{OH})_{2}$ to $\mathrm{NiOOH}$ because of the removal of $\mathrm{NiOOH}$ by borohydride, showing a significantly higher catalytic activity of the Ni/Zn-Ni electrode for borohydride oxidation.

\section{Conclusions}

A smooth nickel electro-catalyst and a $\mathrm{Ni} / \mathrm{Zn}-\mathrm{Ni}$ electro-catalyst were prepared by electrodeposition. A high surface area nickel electrocatalyst was successfully prepared by an electrodeposition methodology that used the selective removal of $\mathrm{Zn}$. SEM results showed that the alkaline leaching process produced a highly porous catalytic surface that was suitable for the electro-oxidation of borohydride. Cyclic voltammetric measurements and electrochemical impedance spectroscopy showed that the $\mathrm{Ni} / \mathrm{Zn}-\mathrm{Ni}$ electrode was an efficient catalyst for the electro-oxidation of borohydride in an alkaline medium, and its electro-catalytic activity for borohydride oxidation was higher than that of the smooth nickel electrode. During the anodic potential sweep, the electro-oxidation of borohydride resulted in the formation of $\mathrm{NiOOH}$ on the electrode surface and this was then catalyzed by $\mathrm{NiOOH}$.

\section{References}

1 Wang Y, Li L, Hu L, Zhuang L, Lu J, Xu B. Electrochem Commun, 2003, 5: 662

2 Yang C-C. Int J Hydrogen Energy, 2004, 29: 135

3 Yu E H, Scott K. J Power Sources, 2004, 137: 248

4 Agel E, Bouet J, Fauvarque J F. J Power Sources, 2001, 101: 267

5 Song S Q, Wang Y, Shen P L. Chin J Catal, 2007, 28: 752

6 Varcoe J R, Slade R C T, Yee E L H, Poynton S D, Driscoll D 
J. J Power Sources, 2007, 173: 194

7 Varcoe J R, Slade R C T. Electrochem Commun, 2006, 8: 839

8 Matsuoka $\mathrm{K}$, Iriyama $\mathrm{Y}$, Abe T, Matsuoka M, Ogumi Z. $J$ Power Sources, 2005, 150: 27

9 Demarconnay L, Brimaud S, Coutanceau C, Léger J-M. J Electroanal Chem, 2007, 601: 169

10 Chen Y G, Zhuang L, Lu J T. Chin J Catal, 2007, 28: 870

11 Gosselink J W. Int J Hydrogen Energy, 2002, 27: 1125

12 Ströbel R, Oszcipok M, Fasil M, Rohland B, Jörissen L, Garche J. J Power Sources, 2002, 105: 208

13 Li M C, Wang W, Ma C. Chin J Catal, 2009, 30: 1073

14 Kamarudin S K, Daud W R W, Ho S L, Hasran U A. J Power Sources, 2007, 163: 743

15 Ha S, Larsen R, Masel R I. J Power Sources, 2005, 144: 28

16 Morris J H, Gysing H J, Reed D. Chem Rev, 1985, 85: 51

17 Amendola S C, Onnerud P, Kelly M T, Petillo P J, Sharp-Goldman S L, Binder M. J Power Sources, 1999, 84: 130

18 Li Z P, Liu B H, Arai K, Suda S. J Electrochem Soc, 2003, 150: $\mathrm{A} 868$

19 Indig M E, Snyder R N. J Electrochem Soc, 1962, 109: 1104

20 Jasinski R. Electrochem Technol, 1965, 3: 40

21 Gyenge E. Electrochim Acta, 2004, 49: 965

22 Liu B H, Li Z P, Suda S. Electrochim Acta, 2004, 49: 3097

23 Kim J H, Kim H S, Kang Y M, Song M S, Rajendran S, Han S C, Jung D H, Lee J Y. J Electrochem Soc, 2004, 151: A1039

24 Gyenge E, Atwan M, Northwood D. J Electrochem Soc, 2006, 153: A150

25 Atwan M H, Macdonaid C L B, Northwood D O, Gyenge E L. J Power Sources, 2006, 158: 36

26 Ponce-de-León C, Bavykin D V, Walsh F C. Electrochem Commun, 2006, 8: 1655

27 Coowar F A, Vitins G, Mepsted G O, Waring S C, Horsfall J A. J Power Sources, 2008, 175: 317

28 Chatenet M, Molina-Concha M B, Diard J P. Electrochim Acta, 2009, 54: 1687

29 Sanli E, Celikkan H, Uysal B Z, Aksu M L. Int J Hydrogen Energy, 2006, 31: 1920

30 Feng R X, Dong $\mathrm{H}$, Cao Y L, Ai X P, Yang H X. Int $J$ Hydrogen Energy, 2007, 32: 4544

31 Atwan M H, Northwood D O, Gyenge E L. Int J Hydrogen Energy, 2007, 32: 3116

32 Sanli E, Uysal B Z, Aksu M L. Int J Hydrogen Energy, 2008, 33: 2097

33 Atwan M H, Northwood D O, Gyenge E L. Int J Hydrogen Energy, 2005, 30: 1323

34 Lam V W S, Gyenge E L. J Electrochem Soc, 2008, 155:
B1155

35 Raman R K, Choudhury N A, Shukla A K. Electrochem SolidState Lett, 2004, 7: A488

36 Tarozaitè R, Tamašauskaitè-Tamašiūnaite L, Jasulaitienè V. $J$ Solid State Electrochem, 2009, 13: 721

37 Silva R F, de Francesco M, Giorgi L, Campa M C, Cardellini F, Pozio A. J Solid State Electrochem, 2004, 8: 544

38 Antolini E. Mater Chem Phys, 2003, 78: 563

39 King W D, Corn J D, Murphy O J, Boxall D L, Kenik E A, Kwiatkowski K C, Stock S R, Lukehart C M. J Phys Chem B, 2003, 107: 5467

40 Oliveira Neto A, Dias R R, Tusi M M, Linardi M, Spinace E V. J Power Sources, 2007, 166: 87

41 Ensafi A A, Lotfi M, Karimi-Maleh H. Chin J Catal, 2012, 33: 487

42 Zheng Q, Li J H, Chen H C, Chen Q, Zhou B, Shang S, Cai W. Chin J Catal, 2011, 32: 1357

43 Solmaza R, Döner A, Şahin İ, Yüce A O, Kardaş G, Yazıcı B, Erbil M. Int J Hydrogen Energy, 2009, 34: 7910

44 Vértes G, Horányi G. J Electroanal Chem, 1974, 52: 47

45 Robertson P M. J Electroanal Chem Interf Electrochem, 1980, 111: 97

46 Aytaç A, Gürbüz M, Elif Sanli A. Int J Hydrogen Energy, 2011, 36: 10013

47 Miliauskas D, Tarozaitė R, Tamašiūnaitė L T. Mater Sci-Medziagotyra, 2008, 14: 20

48 Geng X, Zhang H, Ye W, Ma Y, Zhong H. J Power Sources, 2008, 185: 627

49 Molina Concha B, Chatenet M. Electrochim Acta, 2009, 54: 6119

50 Grinberg V A, Mayorova N A, Korlyukov A A, Pasynskii A A. Russ J Electrochem, 2010, 46: 1289

51 Nagle L C, Rohan J F. Int J Hydrogen Energy, 2011, 36: 10319

52 Birry L, Lasia A. J Appl Electrochem, 2004, 34: 735

53 Kubisztal J, Budniok A, Lasia A. Int J Hydrogen Energy, 2007, 32: 1211

54 Abdel-Rehim S S, Khaled K F, Abd-Elshafi N S. Electrochim Acta, 2006, 51: 3269

55 Chen L, Lasia A. J Electrochem Soc, 1992, 139: 3214

56 Trasatti S, Petrii O A. Pure Appl Chem, 1991, 63: 711

57 Krstajić N, Popović M, Grgur B, Vojnović M, Šepa D. J Electroanal Chem, 2001, 512: 16

58 Hitz A, Lasia A. J Electroanal Chem, 2001, 500: 213

59 Lasia A. J Electroanal Chem, 1995, 397: 27

60 Chen L, Lasia A. J Electrochem Soc, 1991, 138: 3321

61 Martinez S, Metikoš-Huković M, Valek L. J Mol Catal A, 2006, 245: 114 